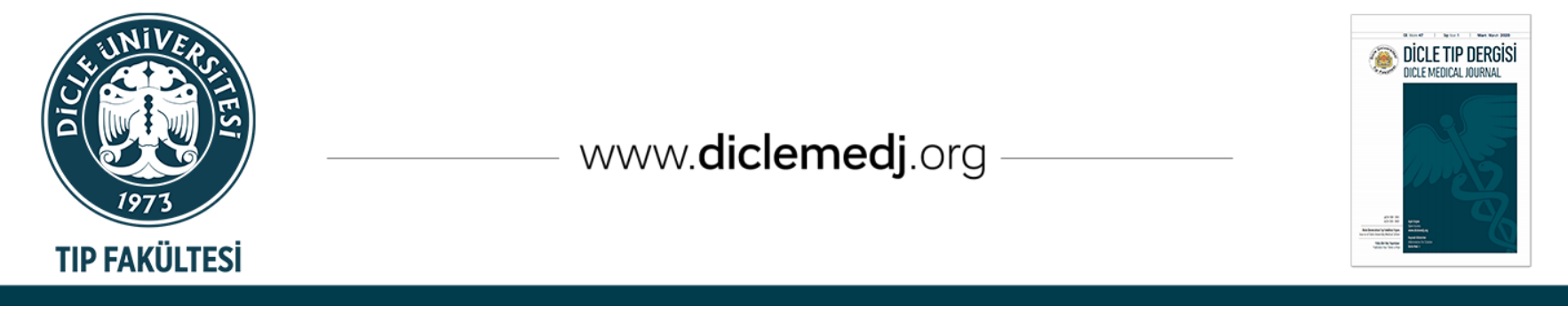

\title{
Kronik Yaygın ve Lokal Ağrılı Hastalarda D Vitamini Düzeyleri ve Yaşam Kalitesi Arasındaki İlişki
}

\author{
Revşa Evin Canpolat Erkan ${ }^{1}{ }_{1}$, Nuriye Mete ${ }^{\left(D_{2}\right.}$, Figen Ceylan Çevik ${ }^{3}$ \\ 1 Diyarbakır Gazi Yaşargil Eğitim ve Araştırma Hastanesi Biyokimya Laboratuvarı Diyarbakir, Türkiye \\ 2 Dicle Üniversitesi Tıp Fakültesi Biyokimya A.B.D. Diyarbakir, Türkiye \\ 3 Fizyopolitan Dal Merkezi Diyarbakir, Türkiye
}

Geliş: 20.11.2019; Revizyon: 13.04.2020; Kabul Tarihi: 19.04.2020

Öz

Amaç: Bölgemizde yaş, ırk, deri rengi, iklim, enlem özellikleri açısından aynı olan FMS, MAS, FM+MAS'lı hastalarda D vitamini düzeyini araştırmak ve hastalık parametreleri ile ilişkisini tespit ederek; Özellikle FMS ve MAS' birlikteliğinde oluşabilecek farkı ortaya koymaktı.

Yöntemler: Dicle Üniversitesi Tıp Fakültesi Fiziksel Tıp ve Rehabilitasyon Anabilim Dalı polikliniğine başvuran ACR 1990 FMS tanı kriterlerine uyan 23 FMS'li, 36 MAS'lı ve her iki tanıyı birden taşıyan 21 hasta ile 39 sağlklı semptomsuz bireyden kan örnekleri alınarak laboratuvarda analiz edildi.

Bulgular: FMS ve FMS+MAS hastalarında normal popülasyonla kıyaslandığında D vitamini düşük bulundu. FMS ve FMS+MAS'ta normal kabul ettiğimiz sınırın altında vitamin D seviyesi tespit edilmesine rağmen sadece FMS'deki düşüklük istatiksel olarak anlamlı bulundu $(\mathrm{p}<0,05)$. D vitamin düzeylerini ortalama olarak FMS'li grupta $16,5 \mathrm{ng} / \mathrm{ml}$, MAS'lı grupta 25,5 ng/ml, FMS+MAS'lı grupta ise $20,6 \mathrm{ng} / \mathrm{ml}$ kontrol grubunda $26,5 \mathrm{ng} / \mathrm{ml}$ seviyelerinde tespit edildi. D vitamin eksikliğinin FMS, MAS, FMS+MAS'lı hastalarda ağrı, uyku bozukluğu, yorgunluk, depresyon, anksiyete üzerine etkilerinin olduğu tespit edilmiştir.

Sonuç: Sonuç olarak FMS ve MAS hastalarında sağlıklı kontrollere göre D vitamini düzeyi düşük bulundu. Bu nedenle ağrı, yorgunluk gibi şikâyetlerle polikliniklere başvuran hastalarda vitamin D düzeyi düşüklügünün olabileceği düşünülüp araştırılmalıdır.

Anahtar kelimeler: Fibromyalji (FMS), Myofasiyal Ağrı Sendromu (MAS), 25-OH Vitamin D 


\title{
25 Oh-Vitamin D Levels In Patients With Chronic Widespread and Local Pain and Association With Quality Of Life
}

\begin{abstract}
Objective: Our aim in this study was to investigate the level of vitamin D in the patients with FMS, MPS, FM+MPS that have the same characteristics in terms of age, race, skin colour, climate and latitude in our region, and, by determining its relation with the illness parameters, to elicit the difference that may be formed with the togetherness of FMS and MPS in particular.

Method: Blood samples that were taken from 23 patients with FMS, 36 with MPS, 21 that have both two diagnoses who matched ACR 1990 FMS diagnosis criteria, 39 healthy subjects with no symptoms that applied to Dicle University, Department of Physical Medicine and Rehabilitation clinics, were analysed in the laboratory.

Results: Vitamin D deficiency detected in patients with FMS and FMS+MPS when compared to healthy population. Even though vitamin D level under the limits of regarded as normal in FMS and FMS+MPS was determined, only the decreasing in FMS was considered as statistically significant $(\mathrm{p}<0,05)$. Vitamin D levels were determined $16.5 \mathrm{ng} / \mathrm{ml}$ in the group with FMS, $25.5 \mathrm{ng} / \mathrm{ml}$ in the group with MPS, $20.6 \mathrm{ng} / \mathrm{ml}$ in the group with FMS + MPS, $26.5 \mathrm{ng} / \mathrm{ml}$ in the control group on average. It was also determined that vitamin D deficiency had effects on the patients with FMS, MPS, FMS+MPS about pain, sleep disturbance, fatigue, depression and anxiety.

Conclusion: Consequently, vitamin D level of the patients with FMS and MPS was found low when compared to healthy controls. The patients who apply to clinics with the complaints of widespread pain and fatigue should be checked by considering the probability of vitamin D level's droopiness.
\end{abstract}

Keyword: Fibromyalgia, Myofascial Pain Syndrome, 25-OH Vitamin D

\section{GíRiş}

Fibromyalji Sendromu (FMS) yaygin ağrı oluşturan romatizmal bir sendromdur ${ }^{1}$. $\mathrm{Bu}$ sendrom daha çok kadınlarda görülmekte olup; semptom olarak kronik yaygın ağrı, uyku bozukluğu, yorgunluk, tutukluk, paresteziler ve yumuşak doku ve eklemlerde subjektif şişlikler oluşturmaktadır².

Bölgesel kronik kas ağrısının en sık sebeplerinden biri de Miyofasiyal Ağr Sendromudur (MAS) ve bu sendrom miyofasiyal yapılar içindeki tetik noktalardan (trigger point) kaynaklanır. Tetik noktalar dışında kas spazmı, kas liflerinde gerginlik ve doku sertlikleri (taut bantlar), yansıyan ağrı, eklem hareketlerinde kısıtlanma, güçsüzlük ve otonomik disfonksiyon görülebilmektedir ${ }^{3}$. Depresyon, uyku bozuklukları gibi klinik belirtiler sıklıkla eşlik etmektedir².

MAS'da lokal ağrının, FMS'de yaygın ağrının olması ve sistemik bulguların daha sık görülmesi iki ağrı sendromu arasında bilinen en önemli farklılıklardır ${ }^{4}$. Bununla birlikte her iki tablo sıklıkla birliktelik göstermektedir 5 .
D vitamini vücudumuzda kalsiyum, fosfor ve kemik metabolizmasının en önemli düzenleyicilerinden biridir6. D vitamininin asıl kaynağı \%90-95'i güneş ışınlarının etkisi ile deride sentezlenen D vitaminidir ve özellikle dışarıdan gıdalara eklenmedikçe alınan vitamin D önem arz etmemektedir?.

Vitamin D eksikliği primer olarak kas-iskelet sistemi şikayetleriyle görülür ve osteomalazinin erken uyaranıdır ${ }^{8,9}$. D vitamini eksikliğinin kas zayıflığındaki mekanizması Vitamin D Reseptör (VDR)'lerin ve kalsidiolün $\quad(25-\mathrm{OH}$ kolekalsiferol) Vitamin D bağımlı reseptörlere (VDR) bağlanma bölgelerinin azalmasıdır9. D vitamini eksikliğinde özellikle tip II fibriller etkilenir. Bu fibriller hızlı, güçlü ve düşmeden kaçınmamızı sağlar ${ }^{10}$.

Bu çalışmadaki amacımız yaygın ağrı oluşturan FMS, lokal ağrı oluşturan MAS, ve her iki ağrılı tablonun birlikte olduğu hastalarda D vitamini düzeylerini araștırmak ve bu düzeylerin hastaların yaşam kalitesinde ve psikolojik durumlarında ortaya çıkan değişikliklerle olan ilişkisini incelemekti. 


\section{YÖNTEMLER}

Çalışmaya fiziksel tıp ve rehabilitasyon polikliniklerine en az 3 aydır mevcut yaygın ve lokal ağrı şikayetleriyle başvuran 23 FMS'li, 36 MAS'lı, her iki tanıyı birden taşıyan 21 hasta ile 39 sağlıklı birey alındı. Çalışmaya başlamadan önce Tip Fakültesi Deneysel Olmayan Klinik Araştırmalar Etik Kurulu'ndan onay alındı (05.03.2009 / 12.653). Çalışmaya alınan bireylerin yazılı onamları alındıktan sonra klinik ve demografik verileri için form dolduruldu.

Her dört grup için kilo, boy, beden kitle indeksi (BMI), ilaç kullanımı, diyet alışkanlığı, sistemik hastalık öyküsü, ilaç kullanım öyküsü, mobilite durumu, şikayet süresi, hassas nokta sayısı, tetik nokta sayısı, VAS ağrı skoru, ağrı, fiziksel aktivite, yorgunluk ve uyku bozukluğu için NHP (Nottingham Sağlık Profili), HAD (Hastane Anksiyete ve Depresyon Ölçeği) içeren bir form dolduruldu.

Çalışmaya katılmayı kabul eden, 15-60 yaş arası, en az üç aydır kronik ağrısı olan ve ACR 1990 FMS tanı kriterlerini ve MAS tanı kriterlerini karşılayan hastalar çalışmaya alındı. Mobilizasyonu herhangi bir nedenle kısitlı olanlar, D vitamini düzeyini etkileyen sistemik hastalığı olanlar; D vitamini, PTH ve Ca düzeylerini etkileyen ilaç kullananlar çalışmaya dahil edilmedi.

Literatürlerde Vitamin D'nin sınır değerleri tartışmalıdır. 25(OH) vit D konsantrasyonuna göre 4 kategoride değerlendirilebilir: Serum $25(\mathrm{OH}) \mathrm{D}<10 \mathrm{ng} / \mathrm{ml}$ ise ciddi Vit D eksikliği, 11$20 \mathrm{ng} / \mathrm{ml}$ arasında ise Vit D eksikliği, 21-30 $\mathrm{ng} / \mathrm{ml}$ arasında ise Vit $\mathrm{D}$ yetmezliği ve $>30$ $\mathrm{ng} / \mathrm{ml}$ ise normal11,12. Bizde yaptığımız çalışmada; FMS, MAS, FMS+MAS'lı hastaları kendi grupları içindeki karşılaştırmalarında D vitamini düzeyi için sınır değerini daha önce yapılan benzeri çalışmalarda olduğu gibi 20 $\mathrm{ng} / \mathrm{ml}$ kabul ettik.
Hasta ve kontrol grubundaki bireylerden 12 saat açlı̆̆ tüplerine alınan kanlar 3500 rpm'de 5 dakika santrfüj edilerek serumları ayrıştırıldı ve bekletilmeden çalıştırıldı. Biyokimyasal parametreler (Ca, P, ALP) enzimatikkolorimetrik yöntemle Architect C16000 (Abbott, USA) otoanalizöründe spektrofotometrik olarak ölçüldü.

25-OH-D3 analizi için EDTA'lı tüplere alınan periferik kanlar 4000 rpm'de 5 dakika santrfüj edildikten sonra elde edilen plazmalar ayrı eppendrof tüplere konup $-80{ }^{\circ} C^{\prime}$ de saklandı. Çalışma 250HD3 HPLC (ImmuChrom, GmbHHeppenheim) kiti ile HPLC (Shimadzu LC $10 \mathrm{~A}$ Kyoto, Japon) sisteminde isocratic metodla C18 reversed faz kolonu kullanılarak UV dedektörde (Shimadzu SPD-10AV Kyoto, Japon) ölçüm yapıldı. Sonuçlar pik alanı değerlendirilerek hesaplandı.

İstatiksel analizler SPSS 13,0 programı ile gerçekleștirildi. FMS, MAS, FMS+MAS ve kontrol grubunda oranlar Oneway Anova testi ile değerlendirildi. Anlamlı olanlar arasındaki değerlendirme Tukey HSD, Dunnett $t$, Tamhane testleriyle yapıldı. FMS, MAS, FMS+MAS ve kontrol grubundaki kesikli değişkenlere Kruskal-Wallis testi ile analiz yapıld. Bu analiz sonucunda anlamlı çıan parametreler için kendi aralarında ki ilişkiler Bonferroni düzeltmeli Mann-Whitney $\mathrm{U}$ testi uygulandı. Vitamin D değerleri ikiye ayrıldı ve bu iki grup arasındaki oranlar ve ortalamalar için t-testi kullanıldı. Korelasyon için Pearson Korelasyon analizi kullanıldı. İstatistiksel analizler $\mathrm{p}<0,05$ ise anlamlı kabul edildiler. Sonuçlar ortalama (mean) \pm SD olarak verildi.

\section{BULGULAR}

Çalışmamızda ki FMS, MAS, FMS+MAS ve kontrol gruplarının klinik ve demografik özellikleri Tablo 1'de verilmiştir. FMS'li hastaların yaş ortalaması 40,3ะ10,8, MAS'lı 
hastaların yaş ortalaması 33,3 $\pm 10,3$, FMS+MAS'lı hastaların yaş ortalaması 36,1 $\pm 9,9$ iken kontrol grubunda 33,6 $\pm 10,2$ olarak tespit edildi ( $p>0.05)$ (Tablo I).

Çalışmamızda; FMS ve FMS+MAS hastalarında normal popülasyonla kıyaslandığında D vitamini eksikliğinin meydana geldiği saptandı. D vitamin eksikliğinin FMS, MAS, FMS+MAS'll hastalarda ağrı, uyku bozukluğu, yorgunluk, depresyon, anksiyete üzerine etkilerinin olduğu tespit edilmiştir (Tablo I).

Tablo I: FMS, MAS, FMS+MAS ve kontrol gruplarının demografik ve klinik özellikleri $( \pm S D)$

\begin{tabular}{|c|c|c|c|c|c|}
\hline Parmetreler & $\begin{array}{l}\text { FMS } \\
n: 23\end{array}$ & $\begin{array}{l}\text { MAS } \\
\text { n:36 }\end{array}$ & $\begin{array}{l}\text { FMS+MA } \\
\text { S n:21 }\end{array}$ & $\begin{array}{l}\text { KONTRO } \\
\text { L n:39 }\end{array}$ & $\mathbf{P}$ \\
\hline Yaş (yıl) & $40,3 \pm 10,8^{a}$ & $33,3 \pm 10,3^{a}$ & $36,1 \pm 9,9^{a}$ & $33,6 \pm 10,0^{a}$ & 0,051 \\
\hline $\begin{array}{l}\text { Cinsiyet \% } \\
\text { (kadın) } \\
\text { (erkek) }\end{array}$ & $\begin{array}{l}100 \\
0\end{array}$ & $\begin{array}{l}83,3 \\
16,7\end{array}$ & $\begin{array}{l}100 \\
0\end{array}$ & $\begin{array}{l}84,6 \\
15,4\end{array}$ & $0,05^{*}$ \\
\hline BMI $\left(\mathbf{k g} / \mathbf{m}^{2}\right)$ & $\begin{array}{l}1,59 \pm 0, \\
05^{\mathrm{a}}\end{array}$ & $\begin{array}{l}1,63 \pm 0,07 \\
\text { b }\end{array}$ & $1,60 \pm 0,06^{a}$ & $\begin{array}{l}1,61 \pm 0,06 \\
\mathrm{ab}\end{array}$ & $0,04^{*}$ \\
\hline Ağrı süresi (ay) & $53,3 \pm 52,3^{\mathrm{a}}$ & $25,3 \pm 24,1^{b}$ & $23,1 \pm 17,8^{b}$ & $0^{c}$ & $0,00^{*}$ \\
\hline VAS Ağrı & $72,1 \pm 15,0^{a}$ & $\begin{array}{l}61,1 \pm 17,5 \\
b\end{array}$ & $\begin{array}{l}66,1 \pm 17,8 \\
\text { ab }\end{array}$ & $0^{c}$ & $0,00^{*}$ \\
\hline $\begin{array}{ll}\text { Hassas } & \text { Nokta } \\
\text { Sayısı } & \end{array}$ & $13,6 \pm 2,0^{a}$ & $0^{\mathrm{b}}$ & $13,3 \pm 2,2^{a}$ & $0^{\mathrm{b}}$ & $0,00^{*}$ \\
\hline $\begin{array}{|ll|}\text { Tetik } & \text { Nokta } \\
\text { Sayısı } & \\
\end{array}$ & $0^{a}$ & $2,2 \pm 1,2^{b}$ & $3,2 \pm 1,3^{c}$ & $0^{a}$ & $0,00^{*}$ \\
\hline HAD-Depresyon & $7,8 \pm 5,4^{\mathrm{a}}$ & $7,1 \pm 4,0^{\mathrm{a}}$ & $9,3 \pm 4,3^{a}$ & $4,6 \pm 3,5^{b}$ & $\begin{array}{l}0,001 \\
*\end{array}$ \\
\hline HAD-Anksiyete & $8,4 \pm 3,8^{a}$ & $8,2 \pm 3,8^{\mathrm{a}}$ & $9,6 \pm 4,3^{\mathrm{a}}$ & $5,2 \pm 3,2^{b}$ & $0,00^{*}$ \\
\hline NHP-Ağrı & $66,6 \pm 28,6^{a}$ & $41 \pm 33,4^{b}$ & $\begin{array}{l}54,5 \pm 28,4^{a} \\
b\end{array}$ & $4,6 \pm 6,8^{c}$ & $0,00^{*}$ \\
\hline $\begin{array}{l}\text { NHP-Fiziksel } \\
\text { Aktivite }\end{array}$ & $33,2 \pm 16,4^{a}$ & $19,4 \pm 18,8^{b}$ & $31,4 \pm 16,8^{a}$ & $4,7 \pm 7,3^{\mathrm{c}}$ & $0,00^{*}$ \\
\hline NHP-Yorgunluk & $74,7 \pm 29,0^{a}$ & $51,1 \pm 40,6^{b}$ & $70,8 \pm 33,9^{a}$ & $7,4 \pm 16,3^{c}$ & $0,00^{*}$ \\
\hline NHP-Uyku & $\begin{array}{l}42,9 \pm 27,2^{a} \\
b\end{array}$ & $30,7 \pm 26,4^{a}$ & $49,2 \pm 29,6^{b}$ & $12,2 \pm 14,3^{c}$ & $0,00^{*}$ \\
\hline
\end{tabular}

$a, b, c, \ldots$ Aynı satırda farklı harflerle gösterilen değerler arasındaki fark istatistiksel açıdan önemlidir. $(p<0,05)$
FMS ve FMS+MAS'ta normal kabul ettiğimiz sinırın altında vitamin D seviyesi tespit edilmesine rağmen sadece FMS'deki düşüklük istatiksel olarak anlaml bulundu $(\mathrm{p}<0,05)$. D vitamin düzeylerini ortalama olarak FMS'li grupta $16,5 \mathrm{ng} / \mathrm{ml}$, MAS'll grupta $25,5 \mathrm{ng} / \mathrm{ml}$, FMS+MAS'll grupta ise 20,6 ng/ml kontrol grubunda $26,5 \mathrm{ng} / \mathrm{ml}$ seviyelerinde tespit edildi (Tablo II). FMS'li grubun \%78,3'ünde, MAS'llarin \%52,8'inde, FMS+MAS'ın $\% 66,7$ 'sinde, kontrolün ise \%11,8'inde D vitamini düzeyinin 20ng/ml'nin altında olduğu tespit edildi $(\mathrm{p}<0,05)$.

Tablo II: FMS, MAS, FMS+MAS ve Kontrol Gruplarının Laboratuvar Parametreleri

\begin{tabular}{|l|c|c|c|c|c|}
\hline $\begin{array}{c}\text { PARMETRELE } \\
\mathbf{R}\end{array}$ & $\begin{array}{c}\text { FMS } \\
\mathbf{n}: \mathbf{2 3}\end{array}$ & $\begin{array}{c}\text { MAS } \\
\mathbf{n}: \mathbf{3 6}\end{array}$ & $\begin{array}{c}\text { FMS+MAS } \\
\mathbf{n}: \mathbf{2 1}\end{array}$ & $\begin{array}{c}\text { KONTRO } \\
\mathbf{L} \\
\mathbf{n}: 39\end{array}$ & $\mathbf{P}$ \\
\hline $\mathbf{C a}$ (mg/d) & $9,4 \pm 0,3^{\mathrm{a}}$ & $9,5 \pm 0,4^{\mathrm{a}}$ & $9,4 \pm 0,4^{\mathrm{a}}$ & $9,2 \pm 0,5^{\mathrm{a}}$ & 0,20 \\
\hline $\mathbf{P}$ (mg/d) & $3,5 \pm 0,5^{\mathrm{a}}$ & $3,5 \pm 0,5^{\mathrm{a}}$ & $3,3 \pm 0,4^{\mathrm{a}}$ & $3,4 \pm 0,5^{\mathrm{a}}$ & 0,58 \\
\hline $\mathbf{A L P}(\mathbf{U} / \mathbf{L})$ & $\begin{array}{c}69,4 \pm 24, \\
8^{\mathrm{a}}\end{array}$ & $\begin{array}{c}68,3 \pm 20,7 \\
\mathrm{a}\end{array}$ & $\begin{array}{c}64,3 \pm 26,9 \\
\mathrm{a}\end{array}$ & $\begin{array}{c}71,0 \pm 34,8 \\
\mathrm{a}\end{array}$ & 0,84 \\
\hline $\begin{array}{l}\mathbf{2 5 ( O H ) D} \\
\mathbf{( n g / m L )}\end{array}$ & $\begin{array}{c}16,5 \pm 11, \\
2^{\mathrm{a}}\end{array}$ & $\begin{array}{c}25,5 \pm 16,9 \\
\mathrm{~b}\end{array}$ & $\begin{array}{c}20,6 \pm 11,2 \\
\mathrm{ab}\end{array}$ & $\begin{array}{c}26,5 \pm 15,2 \\
\mathrm{~b}\end{array}$ & $0,04^{*}$ \\
\hline
\end{tabular}

$a, b, \quad c, \ldots$..Aynı satırda farklı harflerle gösterilen değerler arasındaki fark istatistiksel açıdan anlamlıdır. $(p<0,05)$

FMS'li hastalarda NHP-Ağrı skoru D vitamini 20 ng/ml üstünde olanlarda daha yüksek iken, ağrı süresi D vitamini $20 \mathrm{ng} / \mathrm{ml}$ altında olanlarda daha yüksek bulundu (Tablo III) Yaptığımız korelasyon çalışmasında ise FMS'de fosfor düzeyi ile ağrı süresi arasında ( $r=-0.587, p$ $=0.004$ ) negatif korelasyon, hassas nokta sayısı ile VAS ağrı skoru arasında $(r=0.579, p=0.004)$ pozitif korelasyon tespit ettik. 
Tablo III: FMS'li Hastalarda 20 ng /ml Düzeyinin Altında ve Üstünde Vitamin D Seviyelerine Göre Klinik ve Biyokimyasal Parametreler

\begin{tabular}{|c|c|c|c|}
\hline FMS & $\begin{array}{l}\text { Vitamin } \\
\text { D<20ng/ml } \\
\mathrm{n}: 18\end{array}$ & $\begin{array}{l}\text { Vitamin } \\
\text { D>20ng/ml } \\
\text { n: } 5\end{array}$ & $\mathbf{P}$ \\
\hline $\begin{array}{l}\text { Ortalama } \\
(\mathrm{ng} / \mathrm{ml})\end{array}$ & $11,7 \pm 4,3$ & $33,8 \pm 11,7$ & $0,000^{\star}$ \\
\hline Ağrı Süresi (ay) & $59,1 \pm 54,8$ & $22,5 \pm 12,3$ & $0,031^{*}$ \\
\hline VAS Ağrı Skoru & $69,4 \pm 14,7$ & $82,0 \pm 13,0$ & 0,94 \\
\hline HAD Depresyon & $8,1 \pm 5,6$ & $6,8 \pm 4,8$ & 0,85 \\
\hline HAD Anksiyete & $8,6 \pm 3,8$ & $8,0 \pm 4,3$ & 0,82 \\
\hline NHP-Ağrı & $62,0 \pm 29,9$ & $83,5 \pm 15,7$ & $0,023^{\star}$ \\
\hline NHP-Fiziksel Aktivite & $29,8 \pm 15,1$ & $45,2 \pm 17,0$ & 0,887 \\
\hline NHP-Yorgunluk & $72,0 \pm 30,8$ & $84,8 \pm 20,8$ & 0,30 \\
\hline NHP-Uyku & $40,5 \pm 25,2$ & $51,6 \pm 35,6$ & 0,10 \\
\hline Hassas Nokta Sayısı & $13,2 \pm 2,0$ & $15,0 \pm 1,8$ & 0,59 \\
\hline Kalsiyum(mg/dl) & $9,4 \pm 0,5$ & $9,6 \pm 0,5$ & 0,70 \\
\hline Fosfor(mg/dl) & $3,5 \pm 0,6$ & $3,5 \pm 0,6$ & 0,79 \\
\hline $\mathbf{A L P}(\mathrm{U} / \mathrm{L})$ & $69,1 \pm 24,5$ & $70,8 \pm 28,9$ & 0,94 \\
\hline
\end{tabular}

MAS'lı hastalarda D vitamini 20ng/ml düzeyinin üstünde olanlarda HAD anksiyete skoru, NHPFiziksel Aktivite skoru ve ALP düzeyi daha yüksek bulundu (Tablo IV). Yaptığımız korelasyon çalışmasında MAS'lı hastalarda, fosfor düzeyi ile ağrı süresi ( $r=0.349, \mathrm{p}=0.037$ ) arasında pozitif korelasyon tespit ettik.

Tablo IV: MAS'lı Hastalarda $20 \mathrm{ng} / \mathrm{ml}$ Düzeyinin Altında ve Üstünde Vitamin D Seviyelerine Göre Klinik ve Biyokimyasal Parametreler

\begin{tabular}{|l|l|l|l|}
\hline MAS & $\begin{array}{l}\text { Vitamin } \\
\text { D<20ng/ml } \\
\text { n:19 }\end{array}$ & $\begin{array}{l}\text { Vitamin } \\
\text { D>20ng/ml } \\
\mathbf{n}: \mathbf{1 7}\end{array}$ & $\mathbf{P}$ \\
\hline $\begin{array}{l}\text { Ortalama 25(0H)D } \\
\text { (ng/ml) }\end{array}$ & $14,4 \pm 4,9$ & $39,4 \pm 16,4$ & $\mathbf{0 , 0 0 0 *}$ \\
\hline Ăgrı Süresi (ay) & $25.1 \pm 24.8$ & $25,4 \pm 24,0$ & $\mathbf{0 , 9 0}$ \\
\hline VAS Ağrı Skoru & $60,5 \pm 18,4$ & $61,7 \pm 17,0$ & $\mathbf{0 , 8 8}$ \\
\hline HAD Depresyon & $5,9 \pm 3,2$ & $5,2 \pm 3,6$ & $\mathbf{0 , 7 7}$ \\
\hline
\end{tabular}

\begin{tabular}{|l|l|l|l|}
\hline HAD Anksiyete & $6,7 \pm 1,9$ & $7,2 \pm 5,6$ & $\mathbf{0 , 0 0 4}$ \\
\hline NHP-Ağrı & $32,8 \pm 30,8$ & $22,9 \pm 32,4$ & $\mathbf{0 , 6 1 8}$ \\
\hline NHP-Fiziksel Aktivite & $14,3 \pm 13,1$ & $14,2 \pm 19,8$ & $\mathbf{0 , 0 4 9}$ \\
\hline NHP-Yorgunluk & $43,8 \pm 41,3$ & $25,3 \pm 31,2$ & $\mathbf{0 , 1 8}$ \\
\hline NHP-Uyku & $19,2 \pm 22,4$ & $26,8 \pm 22,9$ & $\mathbf{0 , 3 2}$ \\
\hline Hassas Nokta Sayısı & $2,1 \pm 1,1$ & $2,3 \pm 1,0$ & $\mathbf{0 , 4 4}$ \\
\hline Kalsiyum(mg/dl) & $9,5 \pm 0,6$ & $9,5 \pm 0,5$ & $\mathbf{0 , 2 4}$ \\
\hline Fosfor(mg/dl) & $3,5 \pm 0,5$ & $3,5 \pm 0,5$ & $\mathbf{0 , 8 3}$ \\
\hline ALP(U/L) & $67,0 \pm 14,7$ & $69,7 \pm 26,3$ & $\mathbf{0 , 0 4} *$ \\
\hline
\end{tabular}
$p<0,05$

FMS+MAS'lı hastalarda D vitamini düzeyi 20ng/ml altında olanlarda NHPAğrı skoru, NHP-Fiziksel Aktivite skoru, NHP uyku skoru, NHP Yorgunluk skoru ve D vitamini 20ng/ml'nin üstünde olanlara göre anlamlı derecede daha yüksek bulundu $(\mathrm{p}<0,05)$. (Tablo V). Yaptığımız korelasyon çalışmasında FMS+MAS'll hastalarda 25(OH) D vitamini ile NHP-Ağrı skoru ( $r=-0.567, p=0.008$ ), NHPFiziksel Aktivite skoru ( $r=-0.696, p=0.000$ ), NHP uyku skoru ( $r=-0,575, p=0,006)$, NHP Yorgunluk skoru ( $r=-0,554, p=0,009)$, HAD Depresyon skoru ( $r=-0,494, p=0,032)$, HAD Anksiyete skoru ( $\mathrm{r}=-0.675, \mathrm{p}=0.001)$ arasinda negatif korelasyon varken, ALP ile VAS ağrı skoru ( $\mathrm{r}=0.519, \mathrm{p}=0.016)$, tetik nokta sayısı ( $\mathrm{r}$ $=0.609, \mathrm{p}=0.003$ ) arasinda pozitif korelasyon tespit ettik.

Tablo V: FMS+MAS'lı Hastalarda $20 \mathrm{ng} / \mathrm{ml}$ Düzeyinin Altında ve Üstünde Vitamin D Seviyelerine Göre Klinik ve Biyokimyasal Parametreler

\begin{tabular}{|l|l|l|l|}
\hline FMS+MAS & $\begin{array}{l}\text { Vitamin } \\
\mathbf{D}<\mathbf{2 0 n g} / \mathbf{m l} \\
\mathbf{n}: \mathbf{1 4}\end{array}$ & $\begin{array}{l}\text { Vitamin } \\
\mathbf{D}>\mathbf{2 0 n g} / \mathbf{m l} \\
\mathbf{n}: 7\end{array}$ & $\mathbf{P}$ \\
\hline $\begin{array}{l}\text { Ortalama } \\
\mathbf{2 5 ( 0 H ) D ( n g / m L )}\end{array}$ & $14,1 \pm 4,6$ & $33,4 \pm 9,1$ & $\mathbf{0 , 0 0 0 *}$ \\
\hline Ağrı Süresi (ay) & $20,5 \pm 12,0$ & $28,2 \pm 26,3$ & $\mathbf{0 , 0 0 1 *}$ \\
\hline VAS Ağrı Skoru & $63,5 \pm 12,1$ & $71,4 \pm 12,1$ & $\mathbf{0 , 8 8}$ \\
\hline HAD Depresyon & $9,8 \pm 4,3$ & $2,8 \pm 2,4$ & $\mathbf{0 , 2 9}$ \\
\hline
\end{tabular}




\begin{tabular}{|l|l|l|l|}
\hline HAD Anksiyete & $10,1 \pm 3,9$ & $3,0 \pm 2,3$ & $\mathbf{0 , 1 2}$ \\
\hline NHP-Ağrı & $49,5 \pm 30,8$ & $2,8 \pm 7,6$ & $\mathbf{0 , 0 1 7} *$ \\
\hline NHP-Fiziksel Aktivite & $31,4 \pm 19,1$ & $0,0 \pm 0,0$ & $\mathbf{0 , 0 0 3} *$ \\
\hline NHP-Yorgunluk & $68,6 \pm 35,7$ & $5,6 \pm 14,8$ & $\mathbf{0 , 0 0 2} *$ \\
\hline NHP-Uyku & $43,8 \pm 28,8$ & $5,3 \pm 6,7$ & $\mathbf{0 , 0 0 3} *$ \\
\hline Hassas Nokta Sayısı & $13,2 \pm 2,1$ & $13,5 \pm 2,6$ & $\mathbf{0 , 5 9}$ \\
\hline Kalsiyum(mg/dl) & $9,6 \pm 0,6$ & $9,2 \pm 0,4$ & $\mathbf{0 , 2 3}$ \\
\hline Fosfor(mg/dl) & $3,5 \pm 0,4$ & $3,0 \pm 0,4$ & $\mathbf{0 , 6 4}$ \\
\hline ALP(U/L) & $59,2 \pm 20,1$ & $74,5 \pm 36,7$ & $\mathbf{0 , 3 7}$ \\
\hline * $p<0,05$ & & & \\
\hline
\end{tabular}

MAS'lllarda tetik nokta sayısı 2,2 $\pm 1,2$ iken FMS+MAS'ta 3,2 $\pm 1,3$ idi. FMS ve MAS birlikteliğinde tetik nokta sayısının istatistiksel olarak anlamlı arttığı görüldü $(p<0,05)$. Uyku skorunun FMS+MAS'll hastalarda ciddi bir şekilde etkilendiği tespit edildi $(49,2 \pm 29,6)(\mathrm{p}<$ 0,05) (Tablo I).

\section{TARTIŞMA}

$\mathrm{Bu}$ çalışmanın amacı kronik yaygın ve lokal kas iskelet sistemi ağrısı yapan ve toplumda oldukça yaygın görülen FMS ve MAS hastalarında D vitamini düzeylerini değerlendirmek; D vitamini ile bu hastalarda etkilenen psikolojik durum ve yaşam kalitesi arasındaki ilişkiyi araştırmaktı. Mevcut çalışmada D vitamini düzeyleri sadece FMS ve FMS+MAS olan hastalarda kontrol grubuna göre anlamlı olarak düşük bulunurken sadece MAS olan hastalarda istatistiksel anlaml fark görülmedi.

Al-Allaf ve arkadaşları yapmış oldukları çalışmalar da FMS'li kadınlarda kontrole göre anlamlı düşük vitamin $\mathrm{D}$ düzeyleri tespit etmiştir ${ }^{13}$. Yener yaptığı çalışmada FMS hastalarında \%47 oranında, kontrol grubunda ise \%41 oranında D vitamini eksikliği tespit etmiş ancak gruplar arasında anlamlı bir farklılık saptamamıştır ${ }^{14}$. Demircan ise yapmış olduğu çalışmada FMS'li hasta grubunda D vitamini eksikliği \%46,58, kontrol grubunda ise
\%25,81 olarak saptamış ve farkı istatistiksel olarak anlamlı bulmuştur ${ }^{15}$. Bir başka çalışmada 75 FMS hastasının \%70'inde D vitamini eksikliği saptanmış olup; FMS hastalarının \%13,3'ünde D vitamini eksikliği (25 nmol/L), \%56'sında ise yetersizlik değerleri (25-50 nmol/L) bulunmuştur. Diğer bir çalışmada 150 persistan kas-iskelet ağrısı olan farklı yaş ve etnik gruptaki kadın ve erkek hastada \%95 oranında vitamin D eksikliği saptanmıştır ${ }^{16,17}$. Plotnikkof ve Quigley'in yapmış oldukları çalışmada ise kronik nonspesifik ağrısı olan hastaların \%93'ünde vitamin D düzeyi ortalama olarak $12.08 \mathrm{ng} / \mathrm{ml}$ bulunmuştur. Bu hastaların yaygın ağrı nedenlerinin düşük vitamin $\mathrm{D}$ düzeylerinden kaynaklanabileceğini bildirilmişlerdir ${ }^{16}$. Çidem ve arkadaşlarının yaygın kas iskelet sistemi ağrıları olan 8457 hasta ile yaptıkları çalışmada D vitamini eksikliği prevalansını \%71,7 olarak bulmuşlardır ${ }^{18}$. Noha yaptığı çalışmada Suudi Arabistanda fibromyaljili hastaların hepsinde (\%100) ciddi D vitamini eksikliği $(4.76 \pm 1.46$ $\mathrm{ng} / \mathrm{mL}$ ) bulmuş ve bu hastaların yüksek doz Vitamin D ile tedavi edildiklerinde tümünde klinik bir iyileşme olduğunu bildirmiştir ${ }^{19}$. Labeeb ve arkadaşlarının 53 FMS hasta grubunda serum D vitamini düzeyini 50 kişilik kontrol grubuna göre istatistiksel olarak anlamlı bir azalma tespit etmişlerdir ${ }^{20}$. Mısır'da Olama ve arkadaşları 50 FMS'li hastaların D vitamini düzeyini kontrol hastalarıla karşılaştırmışlar ve FMS hastalarında D Vitamini düzeyini daha düşük bulmuşlardır ${ }^{21}$. Doğru ve arkadaşlarının yaptıkları çalışmada ise D vitamini düşüklüğü olan FMS'li hastaların D vitamini replasmanı sonrası yaşam kalitelerinin yükseldiği görülmüştür ${ }^{22}$. Özgen ve arkadaşlarının yaptığı çalışmada ise FMS'li hastalarin 25(OH)D vitamin düzeyi $18,08 \pm 11,72$ bulunmuştur. Hastaların \% 88,52'sinde, D vitamini normal olarak kabul edilen $30 \mathrm{ng} / \mathrm{ml}$ 'den düşük olarak tespit edilmiştir ${ }^{23}$. Maafi ve arkadaşlarının İran'da yaptıkları çalışmada da FMS hastalarının \% 
88,4'ünde D vitamini düzeylerini kontrol grubuna göre anlamlı derecede düşük bulunmuștur ${ }^{24}$. Bütün bu çalışmalar, bizim çalışmamızda FMS bulunan hastalarda elde ettiğimiz D vitamini bulgularıyla genel olarak örtüşmektedir. Sadece FMS bulunan hastalarımızın yüzde seksene yakınının D vitamini düzeyinin eksiklik sınırının altında olması yaygın ağrıyla başvuran ve/veya FMS düşünülen her hastada $\mathrm{D}$ vitamini düzeyinin değerlendirilmesi gerektiğini göstermektedir.

Düşük D vitamini düzeylerinin daha çok anksiyete ve depresyonla bağlantılı olduğu belirtilmiştir ${ }^{17}$. Sağlıklı gönüllülerde yapılan bir çalışmada, vitamin D'nin kış aylarında pozitif affekti yükselttiği, negatif affekti düşürdüğü bulunmuş ${ }^{25}$. Berk ve arkadaşlarıda D vitamini yetersizliğinin fibromiyaljili hastalarda anksiyete ve depresyonla ilişkili olduğunu bildirmiştir ${ }^{26}$. Schineder ve arkadaşları yapmış oldukları çalışmada vitamin D seviyesinin şizofrenlerde, alkoliklerde ve depresyon hastalarında kontrol grubuna göre istatistiksel olarak anlamlı düşük olduğunu tespit etmişler ancak bunun nedeninin sosyo ekonomik ve beslenme ile ilgili olabileceğini düşünmüşlerdir ${ }^{27}$. Armstrong ve arkadaşlarının yaptığı çalışmada, D vitamini eksikliği $\quad<25$ $\mathrm{nmol} / \mathrm{l})$ ve $\mathrm{D}$ vitamini yetersizliği (25-50 nmol/l) olan hastaların sağlıklı kontrole göre daha yüksek anksiyete ve depresyon skorlarına sahip oldukları tespit edilmiştir ${ }^{17}$. Biz de çalışmamızda FMS, MAS, FMS+MAS'lı hastalarda anksiyete ve depresyon skorlarını kontrole göre istatistiksel olarak yüksek anlamlı bulduk. FMS+MAS'lı hastalar diğer gruplarla karşılaştırıldığında anksiyete ve depresyon skorları belirgin bir artış göstermiş olmakla birlikte istatistiksel anlamlılık bulunmamıştır. Ayrıca FMS+MAS'lı hastalarda anksiyete ve depresyon bakımından D vitamini $20 \mathrm{ng} / \mathrm{ml}$ 'nin altında olanlarda $20 \mathrm{ng} / \mathrm{ml}$ 'nin üstünde olanlara göre çok daha yüksek skorlar elde edilmesine rağmen istatiksel olarak anlamlı bir fark görülmedi. Anksiyete skoru FMS'li hastalardan D vitamini $20 \mathrm{ng} / \mathrm{ml}$ 'nin üzerinde olanlarda 20 $\mathrm{ng} / \mathrm{ml}$ 'nin altında olanlara göre anlamlı bir fark göstermezken MAS'lı hastalarda istatistiksel açıdan anlamlı bir fark tespit edildi. Bununla birlikte özellikle FMS+MAS'lı hasta grubunda hem anksiyete ve depresyon skorları ve hem de yaşam kalitesi skorları ile D vitamini düzeyleri arasında negatif korelasyon bulundu. Diğer gruplarda olmayan bu sonuç her iki durumun bulunduğu hastalarda D vitamini düzeyinin değerlendirilmesinin ve eksik hastalarda suplemente edilmesinin önemine işaret etmektedir. Nitekim D vitamininin kronik yaygın ağrıda ilave edilmesinin etkileriyle ilgili yapılan çalışmaların bir meta-analizinde olumlu etkileri ortaya konmuş fakat ileri çalışmaların gerekliliği vurgulanmıştır28.

D vitamini ile depresyon arasındaki biyolojik mekanizma tam olarak anlaşllamamıştır. Bununla birlikte kalsiyum homeostazını, antioksidan genlerin ekspresyonunu ve serotonin formasyonunu kontrol ederek; inflamatuar sitokinleri azaltıp antiinflamatuar etki ile birlikte mitokondriyal solunumu devam ettirerek depresyonun ortaya çıkmasını önlediği düşünülmektedir ${ }^{29}$. Gloth ve arkadaşları da mevsimsel affektif bozukluğu olan hastalarda bir gruba 100.000 I.U. D vitamini diğer gruba fototerapi vermiş; D vitamini verilen grupta depresyon ölçümlerinde düzelme görülürken; fototerapi verilen hastalarda bir düzelme gözlemlenmemiştir ${ }^{30}$. Roy ve arkadaşları yorgunluktan şikayetçi olanların \%77,2'sinde vitamin D eksikliği saptamışlar ve vitamin $D$ tedavisi ile yorgunluk düzeylerinde önemli ölçüde azalma bulmuşlardır ${ }^{31}$. D vitamini düşüklüğünün kronik kas ağrılarına sahip hastalarda fiziksel aktivitede azalma ile beraber anksiyete ve depresyonuda ağırlaștırdığını göstermektedir ${ }^{32}$. Armstrong ve arkadaşları yaptıkları çalışmada D vitamini eksikliği ve yetersizliği olan hastaların kontrole göre daha 
yüksek anksiyete ve depresyon skorlarına sahip olduğunu bildirmiștir ${ }^{17}$. Demircan ise yapmıș olduğu çalışmada, kontrol grubuna göre FMS'li hastalarda anksiyete ve depresyon skorları istatistiksel olarak anlamlı ancak hasta grubunda D vitamin düzeyleri $20 \mathrm{ng} / \mathrm{ml}$ 'nin altında ve üzerindekiler arasındaki karşıllaştırmada anksiyete ve depresyon skorlarını birbirine yakın bulduğunu bildirmiştir ${ }^{15}$. Yener'in yaptığı çalışmada da depresyon skorları Demircan'in bulgularına benzer olarak, FMS hastalarında daha anlamlı bulunmuş, D vitamini eksik ve normal olgular arasında istatiksel bir farkllık saptanmamıştır ${ }^{14,15}$. Bizim çalışmamızda depresyon ve anksiyete skorları kontrole göre istatistiksel olarak anlamlı düzeyde yüksek bulunmuştur. Bizim çalışmamızda da eşik değerin üstündeki $\mathrm{D}$ vitamini düzeyine sahip FMS+MAS'lı hastalarda uyku, yorgunluk, ağrı, anksiyete ve depresyon skorlarında belirgin bir düzelme tespit edilmiştir

Demircan yapmış olduğu çalışmada hassas nokta sayısını, uyku skorunu kontrole göre yüksek saptamış ve farkı istatistiksel açıdan önemli bulmuştur ${ }^{15}$. Yener de yapmış olduğu çalışmada hassas nokta sayısını, uyku skorunu kontrole göre istatistiksel olarak anlamlı yüksek bulmuştur ${ }^{14}$. Mesci ve arkadaşlarının yaptıkları çalışma sonuçları serum 25(OH)D eksikliğinde gündüz uykululuk sorununun ve yorgunluğun arttığını, fiziksel aktivite düzeyinin azaldığını göstermiştir ${ }^{33}$. Özgen ve arkadaşlarının yaptığı çalışmada FMS'li hastaların hassas nokta sayısı ile azalan 25(OH)D vitamin düzeyi arasında anlamlı bir korelasyon bulmamışlar ${ }^{23}$. Okyay ve arkadaşlarının yaptığı çalışmada FMS hastalarında ciddi bir D vitamini eksikliği tespit etmişler ve bu hastaların D vitamini düzeyi 20 ng/ml'den düşük olanlarda hassas nokta sayısı, Visual Analogue Scale (VAS) ve Fibromyalgia Impact Questionnaire (FIQ) arasinda korelasyon tespit edip ağrı şiddeti, hastalık aktivitesi ve yaşam kalitesinin FMS hastalarında düşük D vitamini düzeyi ile iliş̧ili olabileceğini düşünmüşler ${ }^{12}$. Çalışmamızda da FMS'lilerde ve FMS+MAS'ta hassas nokta sayısını birbirine yakın ve kontrol grubuna göre farkı istatistiksel açıdan önemli tespit ettik. Uyku skorunu ise FMS'lilerde ve FMS+MAS'ta kontrole göre istatistiksel olarak anlamlı yüksek tespit ettik. Hassas nokta sayısı ve uyku problemi bakımından incelendiğinde bizim çalışmamız ile Yener ve Demircan'ın yapmış olduğu çalışma paralellik göstermektedir.

MAS'lılarda tetik nokta sayısı 2,2 $\pm 1,2$ iken FMS+MAS'ta 3,2 $\pm 1,3$ olarak tespit ettik. FMS ve MAS birlikte olduğu zaman tetik nokta sayısı artmıştır ve bu fark istatistiksel olarak önemli bulunmuştur $(p<0,05)$. Uyku skoru açısından FMS ile FMS+MAS istatistiksel olarak anlamllık tespit edilemezken MAS ile FMS+MAS arasında istatistiksel olarak anlamlılık tespit edilmiştir. Uyku skoru FMS+MAS'lı hastalarda ciddi bir şekilde etkilenmektedir.

Çalışmaya alınan ve özellikle sadece FMS'si olan hasta sayısının az olması; çalışma kesitsel olduğu için D vitamini suplementasyonunun hastaların klinik ve psikolojik durumlarına etkisi ile ilgili sonuçların olmaması çalışmamızın başlıca kısıtlılıklarıydı.

Sonuç olarak FMS ve MAS hastalarında sağlıklı kontrollere göre $D$ vitamini düzeyi düşük bulundu. FMS ve MAS birlikteliğinde D vitamini yetersizliğinin psikolojik durum bozulması ve yaşam kalitesinin azalmasıyla daha yakın bir ilişki gösterdiği; Bu nedenle özellikle yaygın ağrı ve yorgunluk gibi şikâyetlerle polikliniklere başvuran hastalarda vitamin $\mathrm{D}$ düzeyi düşüklüğünün olabileceği düşünülüp araştırılmalıdır. Tedaviye D vitamini eklenmesinin FMS ve MAS hastalarında bozulan yaşam kalitesi ve psikolojik durum üzerindeki etkilerinden söz etmek için daha ileri araştırmaların yapılmasına ihtiyaç vardır.

Etik Kurul Kararı: Çalışmaya başlamadan önce Tıp Fakültesi Deneysel Olmayan Klinik 
Araştırmalar Etik Kurulu'ndan onay alındı (05.03.2009 / 12.653).

Çıkar Çatışması Beyanı: Yazarlar çıkar çatışması olmadığını bildirmişlerdir.

Finansal Destek: Bu çalışma her hangi bir fon tarafından desteklenmemiştir.

Declaration of Conflicting Interests: The authors declare that they have no conflict of interest.

Financial Disclosure: No financial support was received.

\section{KAYNAKLAR}

1. Sofu M, Akı S, Eskiyurt N ve ark. Fibromyalji Sendromunda Moklobemid'in Ağrı ve Psikolojik Parametreler Üzerine Etkinliği. Fizik Tedavi Rehabilitasyon Dergisi.1996; 20: 115-21.

2. Gürer G, Sendur Ö.F. Fibromyaljili Hastalarımızın Klinik Özellikleri ile Bulgular Arasındaki Korelasyonlar. Romatizma. 2006; 21: 41-4.

3. Kaya A, Kamanlı A, Saitoğlu M, İlhanlı N. Miyofasiyal Ağrı Sendromlu Hastaların Serum Lipit Düzeyleri. Frrat Tıp Dergisi.2006; 11: 1602.

4. Raj PP, Paradise LA. Myofascial Pain Syndrome and Its Treatment in Low Back Pain. Semin Pain Med. 2004; 2: 167-74.

5. Sahin N, Atik A, Dogan E. Clinical and Demographic Characteristics and Functional Status of the Patients with Fibromyalgia Syndrome. North Clin Istanb. 2014 Dec 8; 1: 8994.

6. Hatun S, Bereket A, Çalıkoğlu AH, Özkan B. Günümüzde D Vitamini Yetersizliği ve Nütrisyonel Rikets. Çocuk Sağlığı ve Hastalıkları Dergisi.2003; 46: 224-41.

7. Atas A, Çakmak A, Soran M. D Vitamin Metabolizması ve Rikets Hastalığı. Bakırköy Tıp Dergisi.2008; 4: 1-7.
8. Heath KM, Elovic EP. Vitamin D Deficiency Implications in the Rehabilitation Setting. Am. J. Phys. Med. Rehabil. 2006; 85: 916-23.

9. Lotfi A, Abdel-Nasser AM, Hamdy A, Omran AA, El-Rehany MA. Hypovtaminosis D in Famele Patients with Chronic Low Back Pain. Clin Rheumatol. 2007; 26: 1895-901.

10. Başaran S, Güzel R, Coşkun-Benlidayı İ. at all. Vitamin D Status: Effects On Quality of Life in Osteoporosis Among Turkish Women. Qual Life Res. 2007; 16: 1492-9.

11. Sozen T, Gogas Yavuz D, Akalın A. ve ark. Metabolik Kemik Has ᄀtalıkları Tanı Ve Tedavi Kılavuzu. Türkiye Endokrinoloji ve Metabolizma Derneği. 1.Baskı. İstanbul: Galenos Yayınevi, 2012: 19-27.

12. Okyay R, Koçyigit B, Gürsoy S. Vitamin D Levels in Women with Fibromyalgia and Relationship Between Pain, Tender Point Count and Disease Activity. Acta Med Mediterr. 2016; 32: 243-7.

13. Al-Allaf A. W, Mole PA, Paterson CR, Pullar T. Bone Health in Patients with Fibromyalgia. Rheumatology. 2003; 42: 1202-6.

14. Yener M. Fibromyaljili Hastalarda Serum 25Hidroksi D Vitamini ve Parathormon Düzeyleri. Uzmanlık Tezi. Süleyman Demirel Üniversitesi Tıp Fakültesi ve Rehabilitasyon A.B.D. 2005.

15. Demircan Z. Fibromiyalji Hastalarında D Vitamini ve Diğer Laboratuar Parametrelerinin Klinik, Emosyonel Durum ve Yasam Kalitesi Üzerine Etkileri. Uzmanlı Tezi. Dicle Üniversitesi Tıp Fakültesi Fiziksel Tıp ve Rehabilitasyon Anabilim Dalı 2008.

16. Plotnikoff GA, Quigley JM. Prevalence of Severe Hypovitaminosis D in Patients with Persistent, Nonspesific Musculoskeletal Pain. Mayo Clin Proc. 2003; 78: 1463-1470.

17. Armstrong DJ, Meenaagh GK. Vitamin Deficiency is Associated with Anxiety and 
Depression in Fibromyalgia. Clin Rheumatol. 2007; 26: 551-4.

18. Çidem M, Kara S, Sarı H, Özkaya M, Karacan İ. Yaygın Kas-İskelet Ağrısı Olan Hastalarda D Vitamini Eksikliği Prevalansı ve Risk Faktörleri. Journal of Clinical and Experimental Investigations. 2013; 4: 488-91.

19. Noha T. Abokrysha. Vitamin D Deficiency in Women with Fibromyalgia in Saudi Arabia. Pain Medicine 2012; 13: 452-8.

20. Labeeb AA, Al-Sharaki DR. Detection of Serum 25(OH)-vitamin D Level in the Serum of Women with Fibromyalgia Syndrome and its Relation to Pain Severity. Egypt Rheumatol Rehabil. 2015; 42: 196-200.

21. Olama SM, Senna MK, Elarman MM, Elhawary G. Serum vitamin D Level and Bone Mineral Density in Premenopausal Egyptian Women with Fibromyalgia. Rheumatol Int. 2013; 33: 185-92.

22. Dogru A, Balkarli A, Cobankara V, Tunc SE, Sahin M. Effects of Vitamin D Therapy on Quality of Life in Patients with Fibromyalgia Eurasian J Med 2017; 49: 113-7.

23. Ozgen M, Aydoğan AM, Uygur A, Armağan O, Berkan F, Mutlu F.. Evaluation of Vitamin D Levels in Fibromyalgia Syndrome, Osmangazi Journal of Medicine. 2019; 41:161-5.

24. Maafi AA, Ghavidel-Parsa B, Haghdoost A, et al. Serum Vitamin D Status in Iranian Fibromyalgia Patients: According to the Symptom Severity and İlness İnvalidation. Korean J Pain. 2016; 29: 172-8.

25. Özen S, Haspolat K. D Vitamini, Kalsiyum, Kemik Metabolizması ve Psikiyatrik Bozukluklar. Klinik Psikiyatri. 2003; 6: 102-13.
26. Berk M, Sanders KM, Pasco JA, et al. Vitamin D Deficiency May Play a Role in Depression. Medical Hypotheses 2007; 69: 1316-9.

27. Schineider B, Weber B, Frensch A, Stein J, Fritze J. Vitamin D Schizophrenia, Major depression and Alcoholism. Journal of Neural Transmission 2000; 107: 839-42.

28. Yong WC, Sanguankeo A, Upala S. Effect of Vitamin D Supplementation in Chronic Widespread Pain: A Systematic Review and Meta-Analysis. Clin Rheumatol. 2017; Dec;36: 2825-33.

29. Berridge MJ. Vitamin D and Depression: Cellular and Regulatory Mechanisms. Pharmacol Rev. 2017; 69: 80-92.

30. Gloth F.M, Alam W, Hollis B. Vitamin D vs Broad Spectrum Phototherapy in The Treatment Of Seasonal Affective Disorder. J Nutr Health Aging. 1999; $3: 5-7$.

31. Roy S, Sherman A, Monari-Sparks MJ, Schweiker O, Hunter K. Correction of Low Vitamin D Improves Fatigue: Effect of Correction of Low Vitamin D in Fatigue Study (EViDiF Study). N Am J Med Sci. 2014; 6: 396402.

32. Janssen H.C.J.P, Samson M.M, Verhaar H.J.J. Vitamin D Deficiency, Muscle Function, And Falls in Elderly People. Am J Clin Nutr. 2002; 75: 611-5.

33. Mesci E, Mesci N, İçağasıoğlu A. D Vitamini Eksikliğinin Yorgunluk, Gündüz Uykululuk Hali ve Fiziksel Aktivite Düzeyi ile İlişkisi. Turk J Phys Med Rehab. 2016; 62: 222-8. 